\title{
Corrigendum: Perspective: Climate Change and the Relocation of Indonesia's Capital to Borneo
}

\author{
Paige Van de Vuurst and Luis E. Escobar* \\ Department of Fish and Wildlife Conservation, Virginia Polytechnic Institute and State University, Blacksburg, VA, \\ United States
}

Keywords: Anthropocene, biodiversity, flooding, impacts, Indonesia

\section{A Corrigendum on}

Perspective: Climate Change and the Relocation of Indonesia's Capital to Borneo

by Van de Vuurst, P., and Escobar, L. E. (2020). Front. Earth Sci. 8:5. doi: 10.3389/feart.2020.00005

\section{OPEN ACCESS}

Edited and reviewed by: Liangcheng Tan,

Institute of Earth Environment (CAS),

China

*Correspondence: Luis E. Escobar escobar1@vt.edu

Specialty section: This article was submitted to Interdisciplinary Climate Studies, a section of the journal

Frontiers in Earth Science

Received: 12 February 2020

Accepted: 26 February 2020

Published: 12 March 2020

Citation:

Van de Vuurst $P$ and Escobar LE (2020) Corrigendum: Perspective: Climate Change and the Relocation of Indonesia's Capital to Borneo.

Front. Earth Sci. 8:71. doi: 10.3389/feart.2020.00071
In the original article, there was an error. Page two, paragraph three stated that the estimated cost of moving the political capital from Java to Borneo was 3.3 billion United States dollars, the correct number is 33 billion. A correction has been made to the 4th paragraph

"In response to the considerable sociological issues, pollution, traffic, climate change risks, and political influences, the government of Indonesia has recently announced plans to relocate the country's political capital to the more sparsely inhabited island of Borneo (Figure 1), potentially within the eastern Kalimantan region (Ritter, 2019; Watts, 2019). This move is estimated to cost nearly $\$ 33$ billion (US), and could signal a new wave of forced relocation or development in tropical areas across the world due to environmental collapse (Thiede and Gray, 2017; Lyons, 2019). This initiative, though made in the good faith of relieving Jakarta of its human burden, could mean that the negative factors driving poor sustainability on Java could be transferred from Jakarta to Borneo, especially during the early stages of moving the capital."

The authors apologize for this error and state that this does not change the scientific conclusions of the article in any way. The original article has been updated.

\section{ACKNOWLEDGMENTS}

The authors thank Tiffany M. Tran for informing them of this error.

\section{REFERENCES}

Lyons, K. (2019). Why is Indonesia Moving its Capital City? Everything you Need to Know. Available at: https:// www.theguardian.com/world/2019/aug/27/why-is-indonesia-moving-its-capital-city-everything-you-need-to-know (accessed November, 2019).

Ritter, M. (2019). "President Joko Widodo: new captial city will be on Borneo," in Proceedings of the Palace Press Conference Aug. 26, 2019, (Jakarta).

Thiede, B. C., and Gray, C. L. (2017). Heterogeneous climate effects on human migration in Indonesia. Popul. Environ. 39, 173-195. doi: 10.1007/s11111-017-0282-2

Watts, J. (2019). Indonesia Announces Site of Capital City to Replace Sinking Jakarta. Available at: https://www.theguardian. com/world/2019/aug/26/indonesia-new-capital-city-borneo-forests-jakarta (accessed September, 2019).

Copyright (c) 2020 Van de Vuurst and Escobar. This is an open-access article distributed under the terms of the Creative Commons Attribution License (CC BY). The use, distribution or reproduction in other forums is permitted, provided the original author(s) and the copyright owner(s) are credited and that the original publication in this journal is cited, in accordance with accepted academic practice. No use, distribution or reproduction is permitted which does not comply with these terms. 